\title{
Incidence of Bacteriuria after Urodynamic Study with or without Antibiotic Prophylaxis in Women with Urinary Incontinence
}

\section{Incidência de bacteriúria após estudo urodinâmico com ou sem profilaxia antibiótica em mulheres com incontinência urinária}

\author{
Elizabeth Yukie Hirakauva ${ }^{1}$ Ana Maria Homem de Mello Bianchi-Ferraro ${ }^{1}$ Eliana Viana Monteiro Zucchi ${ }^{1}$ \\ Marcio Massashi Kajikawa ${ }^{1}$ Manoel João Batista Castello Girão ${ }^{1}$ Marair Gracio Ferreira Sartori ${ }^{1}$ \\ Zsuzsanna Ilona Katalin de Jarmy-Di Bella ${ }^{1}$
} ${ }^{1}$ Department of Gynecology, Universidade Federal de São Paulo,
São Paulo, SP, Brazil

Rev Bras Ginecol Obstet 2017;39:534-540.
Address for correspondence Elizabeth Yukie Hirakauva, PhD, Departamento de Ginecologia da Universidade Federal de São Paulo, Rua Dom Constantino Barradas, 45, apto. 151, Vila Gumercindo, 04134-110, São Paulo, SP, Brazil (e-mail: bethyukie@hotmail.com).

\begin{abstract}
Keywords

- urodynamic study

- urinary incontinence

- urinary infection

- antibiotic prophylaxis
\end{abstract}

Introduction The presence of bacteria in urine is called bacteriuria, which may be symptomatic or asymptomatic. The manipulation of the urinary tract during urodynamic study (UDS), which is an invasive procedure, can result in urinary tract infection (UTI). Studies on the use of prophylactic antibiotics for UDSs are contradictory. Some investigators concluded that they were valuable and others did not. The objective of this study is to evaluate the efficacy of antibiotic prophylaxis before UDS. This is a placebo-control randomized double-blind study.

Methods Two-hundred and seventeen women affected by urinary incontinence were eligible for this study. All patients had presented negative urine culture previous to the UDS. They were randomized in four groups: group A received placebo, group B received $500 \mathrm{mg}$ of levofloxacin, group C received $80 \mathrm{mg}$ trimethoprim and $400 \mathrm{mg}$ sulfamethoxazole and group D received $100 \mathrm{mg}$ of nitrofurantoin. A urine culture was performed 14 days after the UDS.

Results We observed asymptomatic bacteriuria after the UDS in five patients in group $A$, one in group $B$, one in group $C$ and one in group $D$. Only one patient on group $A$ had symptomatic bacteriuria. We didn't observe statistical difference between the groups. When we recategorized the patients in two groups, the incidence of bacteriuria was significantly higher in the placebo group compared with the antibiotic group. Conclusion The conclusion is that antibiotic prophylaxis before the UDS did not reduce the incidence of UTI in women within the target population. received

January 20, 2017

accepted

April 19, 2017

published online

June 30,2017
DOI https://doi.org/

$10.1055 / \mathrm{s}-0037-1604066$.

ISSN $0100-7203$.
Copyright @ 2017 by Thieme Revinter

Publicações Ltda, Rio de Janeiro, Brazil
License terms

c) $(1) \$$ 


\section{Resumo}

\section{Palavras chaves}

- estudo urodinâmico

- incontinência urinária

- infecção urinária

- profilaxia antibiótica
Introdução A presença de bactéria na urina é denominada bacteriúria, que pode ser sintomática ou assintomática. A manipulação do trato urinário pelo estudo urodinâmico (EUD), que é um procedimento invasivo, pode resultar em infecção do trato urinário (ITU). Os estudos sobre o uso de profilaxia antibiótica para EUD são contraditórios. Alguns investigadores concluíram que era necessário e outros não. $\mathrm{O}$ objetivo deste estudo é avaliar a eficácia da antibióticoprofilaxia antes da realização do EUD. Trata-se de um estudo randomizado duplo-cego.

Métodos Duzentas e dezessete mulheres com queixa de incontinência urinária foram recrutadas para este estudo. Todas as pacientes apresentaram urocultura negativa antes do EUD. As pacientes foram randomizadas em quatro grupos: o grupo A recebeu placebo, o grupo B recebeu $500 \mathrm{mg}$ de levofloxacina, o grupo $C$ recebeu $80 \mathrm{mg}$ de trimetoprim e $400 \mathrm{mg}$ de sulfametoxazol e o grupo D recebeu $100 \mathrm{mg}$ de nitrofurantoína. Uma urocultura foi realizada 14 dias após o EUD.

Resultados Observamos bacteriúria assintomática após o EUD em cinco pacientes do grupo A, uma no grupo B, uma no grupo $C$ e uma no grupo $D$. Apenas uma paciente do grupo A apresentou bacteriúria sintomática. Não observamos diferença estatística entre os grupos. Quando recategorizamos as pacientes em dois grupos, a incidência de bacteriúria foi significativamente maior no grupo placebo em comparação com o grupo antibiótico.

Conclusão A conclusão deste estudo é que a antibióticoprofilaxia antes do EUD não reduz a incidência de ITU nesse grupo de mulheres.

\section{Introduction}

The presence of bacteria in urine, also called bacteriuria, may be symptomatic or asymptomatic. When symptomatic, it is characterized by urinary tract infection (UTI), ${ }^{1}$ one of the most prevalent infectious diseases in females. It is more common in women than in men at a ratio of $8: 1$. $^{2}$ The gramnegative bacterium Escherichia coli is the most prevalent uropathogen. ${ }^{3}$ However, the asymptomatic bacteriuria $(A B)^{4}$ does not seem to have important clinical consequences; moreover, $\mathrm{AB}$ is not associated with comorbidities or complications and should not be treated, except during pregnancy. On the other hand, the treatment of $A B$ is associated with a higher rate of recurrent symptomatic UTI and may induce bacterial multidrug-resistance.

The urodynamic study (UDS) is used to evaluate the functional status of the lower urinary tract, providing a pathophysiological basis for urinary symptoms, and it is routinely performed in the investigation of women with lower urinary tract symptoms (LUTS), such as urinary incontinence, voiding dysfunction and neurological disorders. Conventional UDS is divided into a non-invasive test (uroflowmetry) and invasive tests (filling cystometry, pressure-flow study and the assessment of leak point pressure). The invasive UDS involves the use of a small catheter to fill the bladder and to record measurements. ${ }^{5}$ Although the UDS is considered a low-morbidity test, the following mild and self-limited complications are reported, mainly due to catheterization: dysuria, hematuria, voiding difficulty and bacteriuria. ${ }^{6}$

The incidence of bacteriuria in women after UDS ranges from 1,5 to $30 \%{ }^{7-10}$ Although most of cases are benign, this condition is a potential risk factor for complicated urinary infections such as pyelonephritis. ${ }^{11}$ To reduce the risk of bacteriuria, it is well established that catheterization should be performed under aseptic technique and with adequate lubrication. Unfortunately, it is unclear whether antibiotic prophylaxis prevents bacteriuria after UDS.

Many of the existing studies were not randomized controlled trials, and employed a wide range of antibiotic regimens in heterogeneous groups of patients. ${ }^{12}$

The objective of this study is to evaluate the incidence of bacteriuria after UDS and the efficacy of antibiotic prophylaxis before UDS in women, using different antibiotic regimens.

\section{Methods}

This randomized double-blind study was performed in the department of gynecology at a university in the state of São Paulo from January of 2009 to December of 2012. A random number table created the randomization. The sample size was established expecting to find $10 \%$ of differences between the groups with $5 \%$ of significance levels. Therefore, 212 patients were necessary for the study, 53 per group.

An ethical committee approved the study and all patients gave their informed consent before the UDS. A total of 236 women with LUTS undergoing UDS were recruited.

All patients were screened for bacteriuria before the exam and only patients with negative urine culture were eligible for the study. Positive urine culture was considered when $>10^{5}$ organisms $/ \mathrm{mL}$ of a single species was isolated.

The exclusion criteria were the following: positive urine culture at screening procedure, allergy to specific antibiotics, 
pregnancy, diabetes mellitus, intermittent self-catheterization, patients with permanent urinary catheter, current antibiotic treatment, antibiotic treatment within two weeks before the UDS, clinical evidence of UTI and genital prolapse exceeding the genital hiatus.

From a total of 236 patients, 19 women were excluded because they provided no urine sample before the UDS, or had significant bacteriuria before the procedure. Group A received placebo, group B received $500 \mathrm{mg}$ of levofloxacin, group $C$ received $400 \mathrm{mg}$ of sulfamethoxazole and $80 \mathrm{mg}$ of trimethoprim (SMZ-TMP) and group D received $100 \mathrm{mg}$ of nitrofurantoin. One single tablet was given to the patients 30 minutes before the UDS.

The remaining 217 patients (average age of 49,1 years-old, ranging from 23 to 82 ) were randomized into four groups: 63 patients in Group A, 59 patients in Group B, 48 patients in Group C and 47 patients in Group D.

The UDS was performed using a multichannel urodynamic device (Dynapack 2 Slim, São Paulo, SP, Brazil) in accordance with the standards prescribed by the International Continence Society and the International Urogynecological Association. ${ }^{13}$ The patients were asked to completely empty their bladder and urinary flow rate was initially measured.

Before the catheterization, the vulva and external urethral meatus were disinfected with sterile aqueous solution that contained $10 \%$ povidone iodine. After adequate lubrication with a sterile $2 \%$ lidocaine gel, the urethra was catheterized with a $4 \mathrm{~F}$ pressure catheter and a $6 \mathrm{~F}-$ filling catheter. A $10 \mathrm{~F}$ rectal balloon catheter was introduced into the rectum to measure the intra-abdominal pressure. All catheters were connected to the urodynamic machine and were filled with a sterile normal saline solution. The filling cystometry was performed at the filling rate of $50 \mathrm{ml} / \mathrm{min}$, with a sterile normal saline solution at room temperature, until maximum bladder capacity was reached. The pressure-flow study was performed with all catheters in situ, and the catheters were removed at the end of the investigation. The entire exam lasted $\sim 30$ minutes.

All patients were instructed to collect midstream urine samples for microbiology laboratory analysis 14 days after the UDS. Significant bacteriuria was considered when $>10^{5}$ organisms/ml of single bacteria were isolated.

Groups A, B C and D were compared regarding body mass index (BMI), parity and menopause status and there were no differences between them (-Table 1 ).

However, because of the low frequency of bacteriuria in this study $(N=9)$, we opted for including all the patients who received prophylactic antibiotics (B, C and D) into a single group, totalizing 154 patients. Therefore, the comparable groups were antibiotic group $(N=154)$ in contrast with placebo group $(N=63)$, and again there were no differences regarding BMI, parity and menopause status (-Table 2).

All data were entered into the Statistical Package for Social Sciences (SPSS Inc., Chicago, IL, USA), version 16.0 for statistical analysis and graphic representation. A likelihood-ratio test and a Fisher exact test were used to compare the prevalence of significant bacteriuria after the UDS in the different groups, and a Student $t$-test and an analysis of variance (ANOVA) test were used for the comparison of continuous variables. To compare the groups concerning BMI and parity, the model ANOVA was used, and, when necessary, the nonparametric Kruskal-Wallis test. To compare the groups in relation to menopause status, the Chisquare test was used. A significance level of 0.05 was established for statistical analysis.

Table 1 Demographic information regarding groups A, B, C and D

\begin{tabular}{|c|c|c|c|c|c|}
\hline Groups & $\begin{array}{l}\text { A } \\
\text { Placebo }\end{array}$ & $\begin{array}{l}\text { B } \\
\text { Levofloxacin }\end{array}$ & $\begin{array}{l}\text { C } \\
\text { SMZ-TMP }\end{array}$ & $\begin{array}{l}\text { D } \\
\text { Nitrofurantoin }\end{array}$ & $p$ \\
\hline \multicolumn{6}{|l|}{ BMI $\left(\mathrm{kg} / \mathrm{m}^{2}\right)$} \\
\hline Mean \pm SD & $25.71 \pm 3.38$ & $26.14 \pm 3.67$ & $25.79 \pm 2,90$ & $26.51 \pm 4.23$ & $0.657^{+}$ \\
\hline Median (Min-Max) & $26(17-35)$ & $26(19-35)$ & $25.5(21-34)$ & $26(20-39)$ & \\
\hline \multicolumn{6}{|l|}{ Age (years) } \\
\hline Mean \pm SD & $50.3 \pm 9.10$ & $48.8 \pm 10.50$ & $49.8 \pm 10.30$ & $47.2 \pm 9.90$ & $0.422^{+}$ \\
\hline Median (Min-Max) & $51(29-70)$ & $49(23-71)$ & $49(33-77)$ & $45(28-82)$ & \\
\hline \multicolumn{6}{|l|}{ Parity } \\
\hline Mean \pm SD & $3.19 \pm 1, .64$ & $3,34 \pm 1.70$ & $3.15 \pm 1, .09$ & $2.87 \pm 1.15$ & $0.613^{*}$ \\
\hline Median (Min- Max) & $3(0-9)$ & $3(0-9)$ & $3(1-6)$ & $3(0-6)$ & \\
\hline \multicolumn{6}{|l|}{ Menopause } \\
\hline No (\%) & $30(47.6)$ & $34(57.6)$ & $24(50)$ & $30(63.8)$ & $0.324^{\#}$ \\
\hline Yes (\%) & $33(52.4)$ & $25(42.4)$ & $24(50)$ & $17(36.2)$ & \\
\hline Total n (\%) & $63(29 \%)$ & 59 (27.2\%) & $48(22 \%)$ & 47 (21.6\%) & \\
\hline
\end{tabular}

Abbreviations: BMI, body mass index; Kg/m², kilograms/square meters; Min, minimum; Max, maximum; SD, standard deviation; SMZ-TMP, sulfamethoxazole - trimethoprim.

ANOVA test ${ }^{+}$, Kruskal-Wallis test ${ }^{*}$, Chi-square test ${ }^{*}$. 
Table 2 Comparison of recategorized groups antibiotics and placebo in relation to variables BMI, parity and menopause

\begin{tabular}{|c|c|c|c|c|}
\hline Groups & $\begin{array}{l}\text { Antibiotic } \\
\text { B, C, D }\end{array}$ & $\begin{array}{l}\text { Placebo } \\
\text { A }\end{array}$ & Total & $p$ \\
\hline \multicolumn{5}{|l|}{ BMI $\left(\mathrm{kg} / \mathrm{m}^{2}\right)$} \\
\hline Mean + SD & $26.14 \pm 3.63$ & $25.71 \pm 3.38$ & $26.02 \pm 3.56$ & $0.421^{\&}$ \\
\hline Median (Min-Max) & 26 (19-39) & $26(17-35)$ & $26(17-39)$ & \\
\hline \multicolumn{5}{|l|}{ Age (years) } \\
\hline Mean + SD & $48.6 \pm 10.2$ & $50.3 \pm 9.1$ & $49.1 \pm 9.9$ & $0.281^{\&}$ \\
\hline Median (Min-Max) & $48(23-82)$ & $51(29-70)$ & $49(23-82)$ & \\
\hline \multicolumn{5}{|l|}{ Parity } \\
\hline Mean + SD & $3.14 \pm 1.38$ & $3.19 \pm 1.64$ & $3.15 \pm 1.46$ & $0.804^{\&}$ \\
\hline Median (Min-Max) & $3(0-9)$ & $3(0-9)$ & $3(0-9)$ & \\
\hline \multicolumn{5}{|l|}{ Menopause } \\
\hline No (\%) & $88(57.1)$ & $30(47.6)$ & $118(54.4)$ & $0.201^{\#}$ \\
\hline Yes (\%) & 66 (42.9) & $33(52.4)$ & $99(45.6)$ & \\
\hline Total & 154 (70.9\%) & $63(29.1 \%)$ & $217(100)$ & \\
\hline
\end{tabular}

Abbreviations: BMI, body mass index; $\mathrm{Kg} / \mathrm{m}^{2}$, kilograms/square meters; Min, minimum; Max, maximum; SD, standard deviation.

Student $t$-test ${ }^{\&}$, Chi-square ${ }^{\#}$.

\section{Results}

No adverse reactions were observed among patients who had received antibiotics.

- Tables 1 and $\mathbf{2}$ demonstrate that there was no difference in BMI, age, parity or menopausal status among the groups. All groups were homogeneous ( $p>0.05)$.

Patients with positive urine culture had higher age and parity than the patients with negative urine culture. Also, the percentage of postmenopausal patients is higher in the group with positive urine culture than in the one with negative urine culture ( - Table 3 ).
A total of nine patients $(4,1 \%)$ presented positive urine culture 14 days after the UDS: one patient in Group B, one in Group C, one in Group D and six in the placebo group (Group A). There was no statistical difference in significant bacteriuria among the groups, $p=0.125$ ( - Table 4). The placebo group had a significantly higher percentage of positive urine culture in contrast with the ATB group, 6 versus 3, $p=0.019$ (-Table 5).

From the total of nine patients with positive bacteriuria, only one patient in group A demonstrated symptoms of UTI, such as dysuria, polacyuria and pelvic pain 1 week after UDS.

Table 3 Comparison of the results of urine culture in relation to BMI, parity and menopausal variables

\begin{tabular}{|c|c|c|c|}
\hline Variable urine culture & negative & positive & $p$ \\
\hline \multicolumn{4}{|l|}{ BMI } \\
\hline Mean (SD) & $25,95(3.53)$ & $27,56(4.07)$ & $0.186^{* * * *}$ \\
\hline Median (Min-Max) & $26(17-39)$ & $28(22-34)$ & \\
\hline \multicolumn{4}{|l|}{ Age (years) } \\
\hline Mean (SD) & $48.8 \pm 9.9$ & $55.9 \pm 8.8$ & $0.036^{* * *}$ \\
\hline Median (Min-Max) & $48.5(23-82)$ & $52(46-70)$ & \\
\hline \multicolumn{4}{|l|}{ Parity } \\
\hline Mean (SD) & $3.1(1.41)$ & $4,44(1.94)$ & $0.006^{* * *}$ \\
\hline Median (Min-Max) & $3(0-9)$ & $4(2-9)$ & \\
\hline \multicolumn{4}{|l|}{ Menopause } \\
\hline No & $116(55.8)$ & $2(22.2)$ & $0.049^{\# \#}$ \\
\hline Yes & $92(44.2)$ & $7(77.8)$ & \\
\hline Total & $208(100)$ & $9(100)$ & \\
\hline
\end{tabular}

Abbreviation: Min, minimum; Max, maximum; SD, standard deviation.

${ }^{* * *}$ Student $t$-test; ${ }^{\# \#}$ Fisher exact test. 
Table 4 Comparison of groups with respect to significant bacteriuria

\begin{tabular}{|l|l|l|l|l|l|l|}
\hline & Group A & Group B & Group C & Group D & Total & $p^{\#}$ \\
\hline Negative Urine Culture & 57 & 58 & 47 & 46 & 208 & 0.125 \\
\hline Positive Urine Culture & 6 & 1 & 1 & 1 & 9 & 9 \\
\hline Total & 63 & 59 & 48 & 47 & 217 \\
\hline
\end{tabular}

"Likelihood-ratio test.

Table 5 Comparison of antibiotic and placebo groups with respect to significant bacteriuria

\begin{tabular}{|l|l|l|l|l|}
\hline & ATB & Placebo & Total & $p^{\&}$ \\
\hline Negative Urine Culture & 151 & 57 & 208 & 0.019 \\
\hline Positive Urine Culture & 3 & 6 & 9 & \\
\hline Total & 154 & 63 & 217 & \\
\hline
\end{tabular}

Abbreviation: ATB, antibiotic group.

${ }^{\&}$ Fisher test.

The remaining patients experienced no symptoms of UTI, characterizing asymptomatic bacteriuria.

The most common uropathogen was Escherichia coli (77,8\%) followed by Staphylococcus aureus and Enterococcus faecalis $(11,1 \%$ each).

Comparing urodynamic variables in relation to the maximum flow rate, medium flow rate, bladder capacity and postvoid residue, no difference was found among patients with positive or negative urine culture (-Table $\mathbf{6}$ ).

\section{Discussion}

The UDS is an invasive test associated with low subjective and objective morbidity. It is well tolerated and accepted by the female population, and only a small proportion of patients experience a mild degree of pain, anxiety and embarrassment - complications which could be prevented by adequate previous exam orientation. ${ }^{14,15}$

Wide-ranging rates of significant bacteriuria have been reported after UDS in patients without antibiotic prophylaxis. Okorocha et $\mathrm{al}^{9}$ reported a rate of $19.6 \%$ of positive urine culture $48-72 \mathrm{~h}$ after UDS. Bombieri et $\mathrm{al}^{8}$ found an overall incidence of $8 \%$ of significant bacteriuria. Urine specimen were obtained 2 to 7 days after UDS, and 4 patients were identified with transient bacteriuria and other 4 patients with positive urine culture only 7 days after the exam. The study concluded that infection could have been initiated either at the time of the test or later due to minor trauma after urethral catheterization.

Table 6 Comparing urodynamic variables in relation to the maximum flow rate, medium flow rate, bladder capacity and postvoid residual

\begin{tabular}{|c|c|c|c|c|}
\hline Urine culture & Negative & Positive & Total & $p$ \\
\hline \multicolumn{5}{|c|}{ Maximum flow rate $(\mathrm{mL} / \mathrm{s})$} \\
\hline Mean (SD) & $22.8(8,97)$ & $24.44(6.71)$ & $22.87(8.88)$ & 0.588 \\
\hline Median (Min-Max) & $21(6-56)$ & $25(15-35)$ & $21(6-56)$ & \\
\hline \multicolumn{5}{|c|}{ Medium flow rate $(\mathrm{mL} / \mathrm{s})$} \\
\hline Mean (SD) & $11.92(4.96)$ & $13.44(6,78)$ & $11.98(5.04)$ & 0.375 \\
\hline Median (Min-Max) & $11(2-26)$ & $12(6-28)$ & $11(2-28)$ & \\
\hline \multicolumn{5}{|c|}{ Bladder capacity (mL) } \\
\hline Mean (SD) & $396.44(90,2)$ & $408.67(95,45)$ & 396.95 (90.23) & 0.692 \\
\hline Median (Min-Max) & $400(200-700)$ & $400(270-508)$ & $400(200-700)$ & \\
\hline \multicolumn{5}{|c|}{ Postvoid residual (mL) } \\
\hline Mean (SD) & $10.15(36.1)$ & $8.89(26.67)$ & $10.1(35.72)$ & 0.917 \\
\hline Median (Min-Max) & $0(0-400)$ & $0(0-80)$ & $0(0-400)$ & \\
\hline Total & 208 & 9 & 217 & \\
\hline
\end{tabular}

Abbreviations: Min, minimum; Max, maximum; mL, milliliters; mL/s, milliliters/seconds; SD, standard deviation. 
Quek and Tay ${ }^{6}$ observed that the bacteriuria found in patients 7 days after UDS resolved spontaneously in $70 \%$ of the cases, 14 days after the test, without antibiotic therapy, concluding that most of the urinary infection cases are selflimited. Based on this study's conclusions, we chose to collect midstream urine samples for microbiology laboratory analysis 14 days after UDS.

In our study, the incidence of bacteriuria 14 days after UDS was $9.5 \%$ in the placebo group. Since all patients had sterile urine culture before the procedure, it is considered that bacteriuria resulted from the catheterization during the UDS. However, only one patient was symptomatic, accounting for only $0.5 \%$ of UTI in the total of our study.

Although we did not find statistical significance in the incidence of significant bacteriuria between the four groups separately, when we divided the patients into two groups (placebo versus antibiotic prophylaxis), it has been observed that patients who received placebo experienced more positive urine culture (9.5\%) than the antibiotic group (1.9\%). Based on these findings, antibiotic prophylaxis substantially reduced the bacteriuria.

Kartal et $\mathrm{al}^{16}$ evaluated the effectiveness of a single $500 \mathrm{mg}$ dose of oral ciprofloxacin for preventing bacteriuria after UDS and concluded that urinary infection decreased from 14 to $1 \%$ with antibiotic prophylaxis.

Peschers et $\mathrm{al}^{17}$ determined the efficacy of cotrimoxazole administration after UDS to prevent UTIs. Unfortunately, they did not find differences between the groups due to the small size of the sample.

In 2012, a systematic review concluded that prophylactic antibiotics reduced the risk of bacteriuria after UDSs among the female population; moreover, the number of patients who needed to be treated with antibiotics to prevent bacteriuria was of 13.4. Unfortunately, there is not enough evidence suggesting that the prophylactic antibiotics would also reduce symptomatic and complicated UTIs. ${ }^{18}$

The low incidence of bacteriuria after UDS, which is sometimes transient, and the lack of evidence of real benefits of prophylaxis on reducing asymptomatic bacteriuria have led some authors to recommend the use of antibiotics after UDS only in high-risk patients. Choe et $\mathrm{al}^{19}$ considered that patients with recurrent UTI and a previous history of urologic procedures are susceptible to developing bacteriuria after UDS. Dass et $\mathrm{al}^{20}$, in accordance to our study, observed that older women experienced a significantly increased risk of urinary infection after UDS.

We also found that postmenopausal women demonstrated higher rates of positive urine culture, which illustrates that climacteric patients have an increased risk of UTIs due to the fact that the decrease of vaginal lubrication reduces the number of lactobacillus, which can be the cause of the growth of vaginal bacteria. ${ }^{21}$ In our study, patients with positive urine culture had the mean parity higher, but they did not have more genital prolapse or post-void residue.

The poor correlation between the occurrence of urinary symptoms and the development of bacteriuria has already been highlighted by others ${ }^{8}$ and is confirmed here. A recent systematic review has reported that the use of prophylactic antibiotics before the UDS must be evaluated, especially concerning the possibility of adverse effects. Antibiotic prophylaxis has reduced the risk of bacteriuria after UDSs in nine trials, but there was not enough evidence to suggest that symptomatic bacteriuria was also reduced. Thus, there is no scientific evidence for this course of prophylactic treatment. $^{22}$

In conclusion, it has been observed that patients who did not receive antibiotic prophylaxis before UDS developed bacteriuria 14 days after the examination more frequently than those who received antibiotic prophylaxis. However, the antibiotic prophylaxis before the UDS did not reduce the incidence of UTI in women within the target population. Within the group who developed bacteriuria 14 days after the UDS, there were more patients in postmenopausal status and with higher parity and age.

\section{Acknowledgments}

Authors declare no conflict of interest. Clinical trial Registration: NCT03106013.

\section{References}

1 Fihn SD. Clinical practice. Acute uncomplicated urinary tract infection in women. N Engl J Med 2003;349(03):259-266

2 Muller EV, Santos DF, Corrêa NAB. [Prevalence of the microorganisms in urinary tract infections of patients attended in the clinical analysis of the Paranaense University - Umuarama]. Rev Bras Anal Clin. 2008;40(01):35-37 Portuguese

3 Stamm WE. Cystitis and urethritis. In: Schrier RW, Gottschalk CW. Diseases of the kidney. 6th ed. Boston: Little, Brown; 1997. p. 895-912

4 Cai T, Mazzoli S, Mondaini N, et al. The role of asymptomatic bacteriuria in young women with recurrent urinary tract infections: to treat or not to treat? Clin Infect Dis 2012;55(06): 771-777

5 Schäfer W, Abrams P, Liao L, et al; International Continence Society. Good urodynamic practices: uroflowmetry, filling cystometry, and pressure-flow studies. Neurourol Urodyn 2002; 21(03):261-274

6 Quek P, Tay LH. Morbidity and significant bacteriuria after urodynamic studies. Ann Acad Med Singapore 2004;33(06):754-757

7 Schaeffer AJ. Catheter-associated bacteriuria. Urol Clin North Am 1986;13(04):735-747

8 Bombieri L, Dance DA, Rienhardt GW, Waterfield A, Freeman RM. Urinary tract infection after urodynamic studies in women: incidence and natural history. BJU Int 1999;83(04):392-395

9 Okorocha I, Cumming G, Gould I. Female urodynamics and lower urinary tract infection. BJU Int 2002;89(09):863-867

10 Maskell R, Pead L, Vinnicombe J. Urinary infection after micturating cystography. Lancet 1978;2(8101):1191-1192

11 Yip SK, Fung K, Pang MW, Leung P, Chan D, Sahota D. A study of female urinary tract infection caused by urodynamic investigation. Am J Obstet Gynecol 2004;190(05):1234-1240

12 Lowder JL, Burrows LJ, Howden NL, Weber AM. Prophylactic antibiotics after urodynamics in women: a decision analysis. Int Urogynecol J Pelvic Floor Dysfunct 2007;18(02):159-164

13 Haylen BT, de Ridder D, Freeman RM, et al. An International Urogynecological Association (IUGA)/International Continence Society (ICS) joint report on the terminology for female pelvic floor dysfunction. Int Urogynecol J Pelvic Floor Dysfunct 2010; 21(01):5-26 
14 Yokoyama T, Nozaki K, Nose H, Inoue M, Nishiyama Y, Kumon H. Tolerability and morbidity of urodynamic testing: a questionnaire-based study. Urology 2005;66(01):74-76

15 Araujo MP, Oliveira Ed, Queiroz GC, et al. [Effect of an urodynamic study on women with urinary incontinence]. Rev Assoc Med Bras (1992) 2007;53(02):122-125

16 Kartal ED, Yenilmez A, Kiremitci A, Meric H, Kale M, Usluer G. Effectiveness of ciprofloxacin prophylaxis in preventing bacteriuria caused by urodynamic study: a blind, randomized study of 192 patients. Urology 2006;67(06):1149-1153

17 Peschers UM, Kempf V, Jundt K, Autenrieth I, Dimpfl T. Antibiotic treatment to prevent urinary tract infections after urodynamic evaluation. Int Urogynecol J Pelvic Floor Dysfunct 2001;12(04):254-257
18 Foon R, Toozs-Hobson P, Latthe P. Prophylactic antibiotics to reduce the risk of urinary tract infections after urodynamic studies. Cochrane Database Syst Rev 2012;10:CD008224

19 Choe JH, Lee JS, Seo JT. Urodynamic studies in women with stress urinary incontinence: Significant bacteriuria and risk factors. Neurourol Urodyn 2007;26(06):847-851

20 Dass AK, Lo TS, Khanuengkitkong S, Tan YL. Bacteriuria and safety of female urodynamic studies. Int Urogynecol J Pelvic Floor Dysfunct 2013;24(04):677-682

21 Raz R. Urinary tract infection in postmenopausal women. Korean J Urol 2011;52(12):801-808

22 Christian R. Do prophylactic antibiotics reduce UTI risk after urodynamic studies? Am J Nurs 2014;114(02):20 